\title{
Climbing Behavior in a Checkered Keelback, Xenochrophis piscator (Schneider 1799), in Central India
}

\author{
Rahul V. Deshmukh ${ }^{1}$, Sagar A. Deshmukh², Swapnil A. Badhekar ${ }^{3}$ \\ ${ }^{1}$ H. No. 26, Teacher colony, Brahmani - Kalmeshwar, Nagpur, M.S. - 441501 (rahul30.snake@gmail.com) \\ ${ }^{2}$ Behind Potdar Nursing Home, Kalmeshwar, Nagpur, M.S. - 441501 (sd.snakefriend@gmail.com) \\ ${ }^{3}$ Tiwaskarwadi, Raipur, Hingana, Nagpur, M.S. - 441110 (swapnilbadhekar86@gmail.com)
}

Photographs by Sagar A. Deshmukh.

$\mathrm{T}$ The Checkered Keelback or Asiatic Watersnake (Xenochrophis piscator) is perhaps the most plentiful snake in India (Whitaker and Captain 2005), and is particularly abundant in central India (Nande and Deshmukh 2007; Deshmukh et al. 2015). This snake can be found in and around bodies of fresh water, including rivers, ponds, impoundments, and paddy fields. Xenochrophis piscator is a strong swimmer and diver and is capable of jumping off the ground (Daniel 2002). It feeds on frog eggs, tadpoles, and adults, and occasionally fish, rodents, and birds (Whitaker and Captain 2005). Herein we record unusual climbing behavior in an aquatic snake. Phansalkar and Gowande (2017) documented a Checkered Keelback climbing a tree in a semi-evergreen forest in the northern Western Ghats, but climbing is an unusual and unexpected behavior for an aquatic snake.

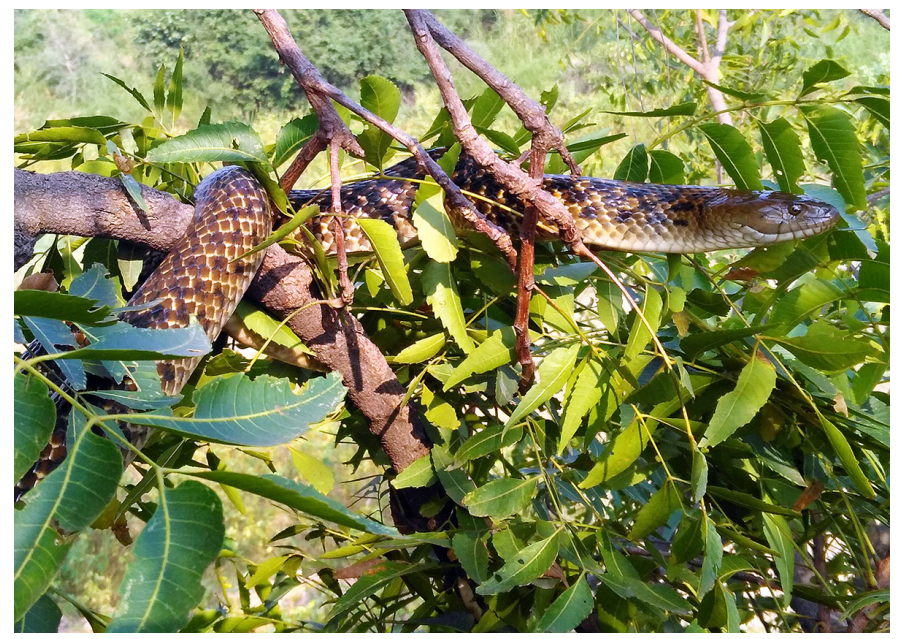

Fig. 1. An adult Checkered Keelback (Xenochrophis piscator) in an Indian Neem Tree (Azadirachta indica).

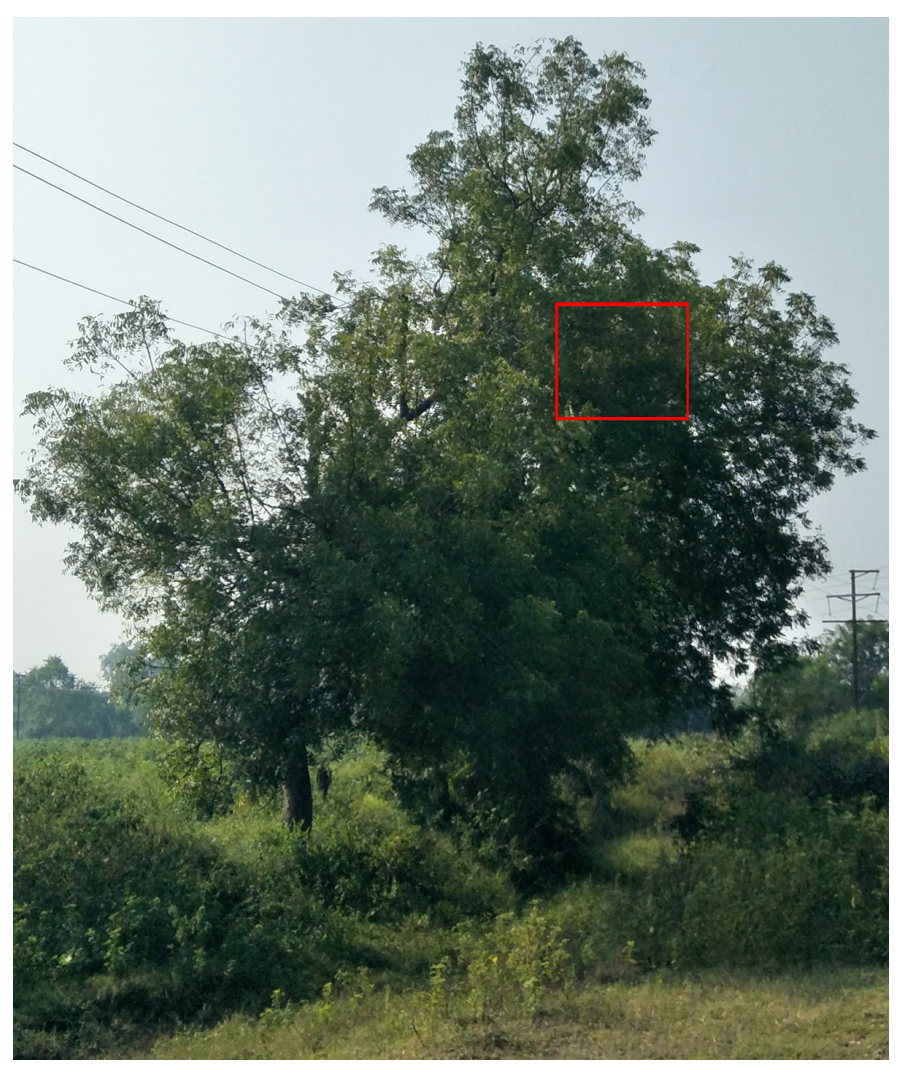

Fig. 2. The red rectangle indicates the location of the Checkered Keelback (Xenochrophis piscator) about $4 \mathrm{~m}$ above the ground in an Indian Neem Tree (Azadirachta indica).

At 0720 hours on 15 October 2017 near Khadak Nala, Kalmeshwar, Nagpur, Maharashtra, in central India $\left(21^{\circ} 14^{\prime} 58^{\prime \prime} \mathrm{N}, 78^{\circ} 53^{\prime} 67^{\prime \prime} \mathrm{E}\right.$; elev. $\left.333.1 \mathrm{~m}\right)$, we found an unsexed adult Xenochrophis piscator (total length $\sim 1,100 \mathrm{~mm}$ ) perched about $7 \mathrm{~m}$ above the ground in an Indian Neem tree (Azadirachta indica; Figs. $1 \& 2$ ). Although two Oriental 
Garden Lizards (Calotes versicolor complex) we saw in the same tree might have been potential prey, these snakes are not known to hunt lizards. Ample cover and suitable basking sites were available in the vicinity, so we are unable to explain why this snake or that observed by Phansalkar and Gowande (2017) climbed a tree.

\section{Acknowledgments}

We are very grateful to Dr. Pratyush Mohopatra, Museum-inCharge, ZSI, Central Zone Regional Centre, Jabalpur; Rahul Khot, Curator- Bombay Natural History Society, Mumbai, Maharashtra; Vithoba Hegde (BNHS, Mumbai); and Dr. B. V. Jadhav (HoD Zoology Dept. B. D. Collage, Patan, Satara). We also thank Sarang Hadke, Dinesh Khate, Manish Buche, Sunil Kanchane, Sushil Pillewan, Mahesh Thawkar, Ajit
Deshmukh, Ankush Kukde, Lalit Nehare, Swapnil Bhondawe, Tushar Thakur, Subham Katgube, and Akash Deshmukh.

\section{Literature Cited}

Daniel, J.C. 2002. The Book of Indian Reptiles and Amphibians. Bombay Natural History Society, Mumbai.

Deshmukh, R.V., A. S.A. Deshmukh, and S.A. Badhekar. 2015. Rescued records of snakes from Nagpur District, Maharashtra with data on unrecorded species. Reptile Rap 17: 34-46.

Nande R. and R. Deshmukh. 2007. Snakes of Amaravati District including Melghat, Maharashtra, with important records of the Indian Egg-eater, Montane Trinket snake and Indian Smooth snake. Zoos' Print Journal 22: 2920-2924.

Phansalkar, P.U. and G.G. Gowande. 2017. Climbing behavior in the Checkered Keelback or Asiatic Water Snake Xenochrophis piscator (Schneider, 1799) (Colubridae: Nitricinae) in the Western Ghats, India. Russian Journal of Herpetology 1: 69-72.

Whitaker, R. and A. Captain. 2004. Snakes of India: The Field Guide. Draco Books, Chennai, India. 